\title{
An Unusually Large Aulocopella Winnipegensis and Associated Demosponges from the Upper Ordovician Beaverfoot Formation, Southeastern British Columbia
}

\author{
J. Keith Rigby \\ Paul A. Johnston
}

Follow this and additional works at: https://scholarsarchive.byu.edu/facpub

Part of the Geology Commons

\section{Original Publication Citation}

Rigby, J. Keith, and Paul A. Johnston. "An Unusually Large Aulocopella Winnipegensis and Associated Demosponges from the Upper Ordovician Beaverfoot Formation, Southeastern British Columbia." Canadian Journal of Earth Sciences = Revue Canadienne des Sciences de la Terre 41.8 (24): 939-47.

\section{BYU ScholarsArchive Citation}

Rigby, J. Keith and Johnston, Paul A., "An Unusually Large Aulocopella Winnipegensis and Associated Demosponges from the Upper Ordovician Beaverfoot Formation, Southeastern British Columbia" (2004). Faculty Publications. 1018.

https://scholarsarchive.byu.edu/facpub/1018

This Peer-Reviewed Article is brought to you for free and open access by BYU ScholarsArchive. It has been accepted for inclusion in Faculty Publications by an authorized administrator of BYU ScholarsArchive. For more information, please contact ellen_amatangelo@byu.edu. 


\title{
An unusually large Aulocopella winnipegensis and associated demosponges from the Upper Ordovician Beaverfoot Formation, southeastern British Columbia
}

\author{
J. Keith Rigby and Paul A. Johnston
}

\begin{abstract}
An unusually large specimen of the rare digitate to bladed Aulocopella winnipegensis Rauff and three relatively normal sized specimens of ashtray-shaped Hudsonospongia? sp. constitute the first record of demosponges from the Upper Ordovician Beaverfoot Formation in southeastern British Columbia and the first record of these taxa from western Canada. Gross form and canal structure are well preserved, but dolomitization and (or) coarse microsphaeroidal silicification have obliterated spicules and other structural details. We interpret these sponges as epifaunal recliners, without means of attachment to the substrate, a life mode rarely encountered in the modern sponge biota.
\end{abstract}

Résumé : Un spécimen de dimension exceptionnellement grande du rare, digité à lamellaire, Aulocopella winnipegensis Rauff et trois autres spécimens de taille relativement normale de Hudsonospongia? sp., en forme de « cendrier », constituent le premier enregistrement de Démosponges de la Formation de Beaverfoot (Ordovicien supérieur) dans le sud-est de la Colombie-Britannique et le premier enregistrement de ces taxons de l'Ouest canadien. La forme générale et la structure des canaux sont en général bien préservées mais une dolomitisation et/ou une silicification microsphéroïdale grossière ont oblitéré les spicules et les autres détails de la structure. Nous interprétons ces éponges comme une épifaune couchée, sans attache au substrat, une mode de vie rarement rencontré dans le biote moderne des éponges.

[Traduit par la Rédaction]

\section{Introduction}

Several demosponges were collected from the Upper Ordovician Richmondian Beaverfoot Formation from exposures in the Top of the World Provincial Park in southeastern British Columbia, Canada (Fig. 1). The productive outcrops are in the Quinn Creek (82G/14) topographic quadrangle. The sponges were collected by Paul Johnston and Robert Campbell, during field work conducted there in 1989, 1992, and 1993, from a measured section and associated talus through the lower part of the dolomitic Beaverfoot Formation (Fig. 2), where the beds are well exposed above Sparkle Lake.

\section{Geologic setting and fossil occurrences}

The Beaverfoot Formation is widely exposed in the southern Rocky Mountains of British Columbia. It is $500 \mathrm{~m}$ thick at its standard section at Pedley Pass and includes strata ranging in age from Late Ordovician (Richmondian) to Early Silurian (Landovery) (Norford 1969). At Sparkle Ridge (Figs. 1, 2) the Beaverfoot Formation rests unconformably on volcaniclastic sediments of the McKay Group, which were probably emplaced in the mid-Early Ordovician (Norford and Cecile 1994). Johnston measured $127 \mathrm{~m}$ of section of the Beaverfoot Formation above the volcaniclastic beds at Sparkle Ridge (Fig. 2, TMP locality L1213). The basal $54 \mathrm{~m}$ of that section are more recessive than the overlying dolomite beds and correspond to the "new unit" of Frey and Norford (1995). These beds consist of limy shales and thin-bedded limestones with some dolomitic beds. The upper $10.5 \mathrm{~m}$ of the new unit is limestone, which is overlain by dolostones that compose the main part of the Beaverfoot Formation. Some beds of the new unit contain a low-diversity fauna of nautiloids, bivalves, gastropods, small aulacerid stromatoporoids, and rare trilobites, brachiopods and colonial tabulate corals. The nautiloid fauna in this unit indicate an early (but not earliest) Richmondian age, equivalent to the onset of Elias' (1991) T2 transgression, as noted by Frey and Norford (1995).

The overlying $70+\mathrm{m}$ of dolostone of the Beaverfoot Formation measured at this section is richly fossiliferous and contains mostly silicified tabulate corals, the rugosan Bighornia, straight cephalopods, rhynchonellid brachiopods, large aulacerid stromatoporoids, and large examples of the

Received 12 January 2004. Accepted 3 May 2004. Published on the NRC Research Press Web site at http://cjes.nrc.ca on 6 August 2004.

Paper handled by Associate Editor J. Jin.

J.K. Rigby. ${ }^{1}$ S-389 ESC, Department of Geology, Brigham Young University, Provo, Utah UT 84602-4606, USA.

P.A. Johnston. Royal Tyrrell Museum of Paleontology, P.O. Box 7500, Drumheller, AB T0J 0Y0, Canada.

${ }^{1}$ Corresponding author (e-mail: rigbyjkeith@qwest.net). 
Fig. 1. Index map to the Sparkle Lake locality, Top of the World Provincial Park, British Columbia. The arrow indicates the site of TMP locality L1213, where the sponges documented here were collected from the Ordovician Beaverfoot Formation.

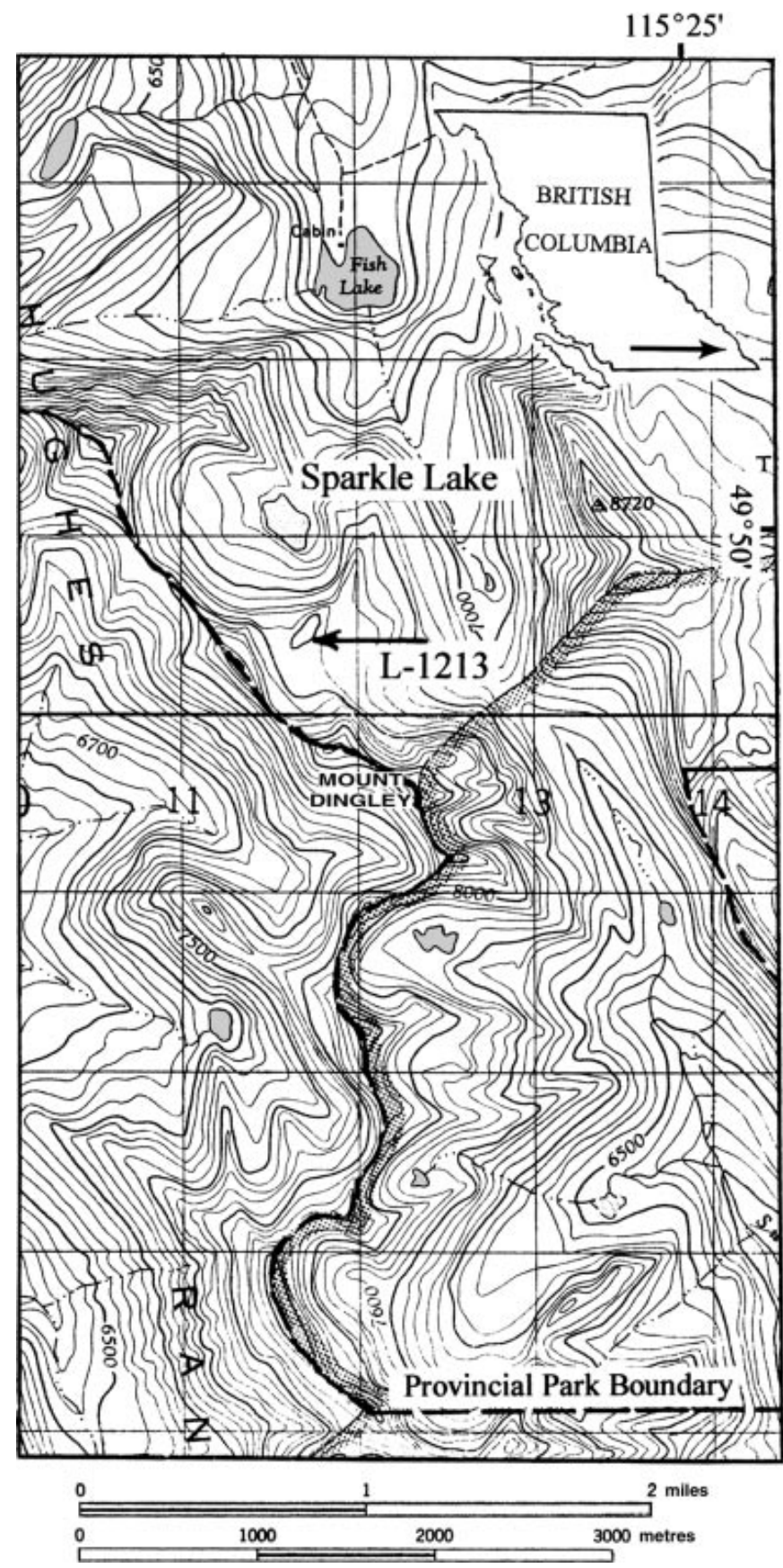

trace fossil Rhizocorallium. Demosponges are rare. A fault occurs at $94.5 \mathrm{~m}$ in the section and repeats the lower part of the Beaverfoot section. About $300+\mathrm{m}$ of Beaverfoot strata are traceable eastward from Sparkle Ridge, but these are poorly fossiliferous (B.S. Norford, written communication, 1993). The nautiloids and aulacerids in the main dolostone of the Beaverfoot Formation in the Sparkle Ridge section suggest a mid- to late Richmondian age for these rocks, and thus equivalency to the R2 regressive event of Elias (1991) (Frey and Norford 1995).
Fig. 2. Stratigraphic section of the Beaverfoot Formation (Fm.) on Sparkle Ridge, above Sparkle Lake, in Top of the World Provincial Park, British Columbia. The sponge figures indicate their occurrences in the main dolostone of the lower part of the formation. The lower recessive unit of the formation rests unconformably on volcaniclastic rocks of the McKay Group. Exposures continue above and below the measured section shown here.

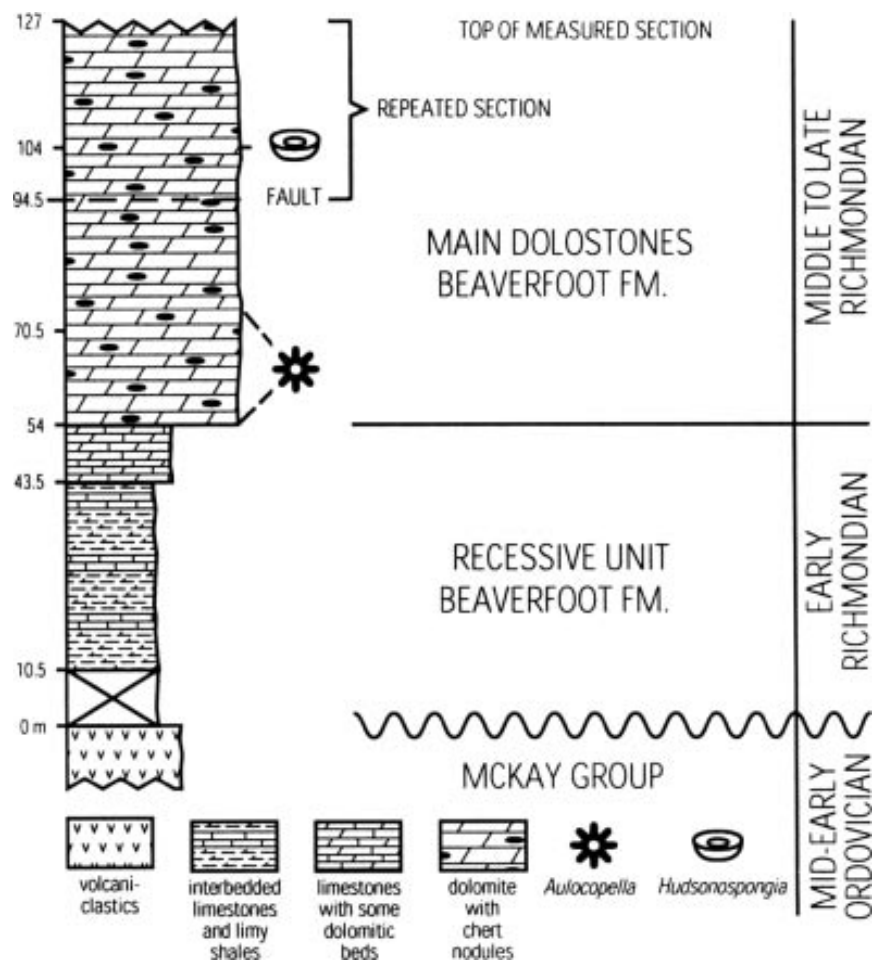

A single specimen of Hudsonospongia? sp. (Fig. 3G) was found in growth position, on a bedding plane at $104 \mathrm{~m}$, which is above the fault interpreted to occur at $94.5 \mathrm{~m}$. Judging from its lithology, and its relative position in the local series of beds, this sponge-bearing bed is likely equivalent to beds at about $16.5 \mathrm{~m}$ above the base of the main Beaverfoot dolostone below the fault, or at $70.5 \mathrm{~m}$ in the section (Fig. 2). The large specimen of Aulocopella winnipegensis (Fig. 3A) occurred in a large burrow-mottled talus block that originated in the lower half of the main Beaverfoot dolostone unit, judging from its lithology and its position relative to in situ beds up slope from which the talus was derived. The other three specimens, two examples of Hudsonospongia? sp., and the smaller fragment of Aulocopella winnipegensis, were found in small talus blocks that were clearly derived from the main Beaverfoot dolostones, judging from their lithology.

Large gastropods and receptaculitid algae, locally common in the lower Beaverfoot Formation elsewhere, are absent in the Sparkle Ridge beds, which is consistent with a relatively deep distal shelf environment interpreted for these deposits (Frey and Norford 1995). Major storms, seismic events, or contour currents may account for alignment of aulacerid stromatoporoids and straight nautiloids in some beds. The new unit filled a deep local depression on the sub-Beaverfoot unconformity (Frey and Norford 1995), and so it and the lower dolomite beds above likely represent a deeper environ- 
ment than is typical of the lower Beaverfoot Formation elsewhere, which may account for the atypical fauna, including demosponges preserved at locality L1213.

\section{Paleoecology}

We interpret both Aulocopella winnipegensis and Hudsonospongia? sp. as unattached epifaunal recliners (Fig. 5). The bases of the Hudsonospongia? sp. specimens are sufficiently exposed to show that neither a holdfast nor an anchoring spicule tuft were present. The undersurface of the A. winnipegensis specimens described here is not visible. However, specimens of this species described elsewhere indicate a short flat-based stalk below the osculum (Rigby and Leith 1989) or a concave matrix-filled surface (Rauff 1895; Rigby and Johnson 2001). In no instance could a case be made for an anchoring holdfast. The sponge probably rested on the distal tips of the blade, with the main part of the undersurface raised above the substrate.

We were unable to find any literature documenting such a habit among extant sponges. PAJ sent enquiries to sponge experts via the Porifera listserver bulletin board and received some anecdotal accounts of extant sponges without holdfasts and living lightly buried or resting on the substrate surface, but in these instances the sponges evidently were detached from their original moorings and were transported. Chris Battershill (written communication 2003) stated: "I have seen many examples of sponges without holdfasts, but they are species which normally are well anchored. What happens in storms is that sponges will often be worked loose. They can remain quite viable for very long times while rolling around on the sea floor. They quickly seal the broken surfaces and look to all intents and purposes as if they never had an attached region. They can have a slightly eroded look in surface topography. Many will reattach if they end up against some rock/coral feature on the sea floor and are held in place (wedged) for any length of time".

Some species of Caribbean sponges occur without holdfasts in sea grass beds (J. Pawlick, written communication 2003), but we wonder if this might not be the same phenomenon as noted by Chris Battershill. We think it improbable that the Hudsonospongia specimens described here represent detached and rehealed sponges as they are consistent in shape, show no evidence of abrasion, and at least one was preserved in life position. Micha Ilan (written communication 2003) noted that some deep-sea Mediterranean species live as unattached recliners, but that these same species may occur elsewhere as attached forms, the substrate type evidently determining the habit. If so, this raises the possibility that Hudsonospongia, which includes some species with holdfasts and some without, may be overly split taxonomically owing to ecophenotypic variation.

\section{Paleobiogeography}

The species Aulocopella winnipegensis and Hudsonospongia? sp. described here constitute the first record of demosponges from the Beaverfoot Formation and the first record of Aulocopella in western Canada. The genus Aulocopella, known only from its type species, is restricted to westcentral Laurentia. In addition to the Beaverfoot specimens described here, only three other specimens of the demosponge A. winnipegensis Rauff are known. Two of these were found in Manitoba, including the type specimen described by Rauff (1895), which was collected from the "Trenton-Gruppe" or Ordovician Red River Formation at Cat Head on the western shore of Lake Winnipeg. A second Manitoba specimen was later collected from glacial debris near Reston, in the southwestern part of the province (Rigby and Leith 1989). The third known specimen of the species was recovered from road gravel near Darby in west-central Montana (Rigby and Johnson 2001) and, like the Reston, Manitoba specimen, its origins are unknown. The occurrence of $A$. winnipegensis in the lower Beaverfoot Formation indicates affinities with the "Red River fauna" described by Foerste (1929) from southern Manitoba, as do the nautiloids (Frey and Norford 1995).

In contrast, Hudsonospongia provides little paleobiogeographic information for it is widespread in Ordovician deposits. For example, in addition to major Canadian occurrences in the Mingan Islands, Quebec (Raymond and Okulitch 1940; Rigby and Desrochers 1995), and less extensive occurrences in Manitoba (Rigby 1971) and the questioned occurrence in British Columbia, reported here, the genus occurs broadly in Ordovician beds in the New England and Appalachian regions of the United States (Raymond and Okulitch 1940), and questionably in northern Utah (Rigby and Jamison 1994). Hudsonospongia has also been reported from several other countries, including China (Liu, et al. 2003), Australia (Rigby and Webby 1988), and Argentina (Beresi and Rigby 1993).

\section{Locality}

Royal Tyrrell Museum locality L1213, Lower Beaverfoot Formation, Richmondian (Ordovician), at $49^{\circ} 49^{\prime} 39^{\prime \prime} \mathrm{N}$, $115^{\circ} 26^{\prime} 48^{\prime \prime} \mathrm{W}$ (Universal Transverse Mercator (UTM) $5520400 \mathrm{mN}$, 611750mE, Zone 11), on the Quinn Creek 15' quadrangle, in the southern part of Top of the World Provincial Park, in southeastern British Columbia. The locality is on the south slope of the range crest, above the cirque at the south end of Sparkle Lake, at an elevation of $~ 8000$ feet (Fig. 1).

\section{Systematic palaeontology}

\section{Depository}

All specimens described here are in invertebrate paleontology collections of the Royal Tyrrell Museum of Paleontology at Drumheller, Alberta, Canada (TMP).

Class Demospongia Sollas, 1875

Subclass Tetractinomorpha Lévi, 1953

Order Lithistida Schmidt, 1870

Suborder Orchocladina Rauff, 1895

Family Streptosolenida Johns, 1994

DIAGNOSIS: Sponges discoidal or palmate but may range to branched funnel-shaped, with skeletons of irregularly oriented dendroclones, which may unite at ray tips to form trabs that may be cored; canal systems may be essentially radial or may be complex and intertwining with exhalant canals that may empty at the surface as individual openings or as clustered oscula, or into a spongocoel. Surface usually smooth but nodes and ridges may be present.

Genus Hudsonospongia Raymond and Okulitch, 1940 

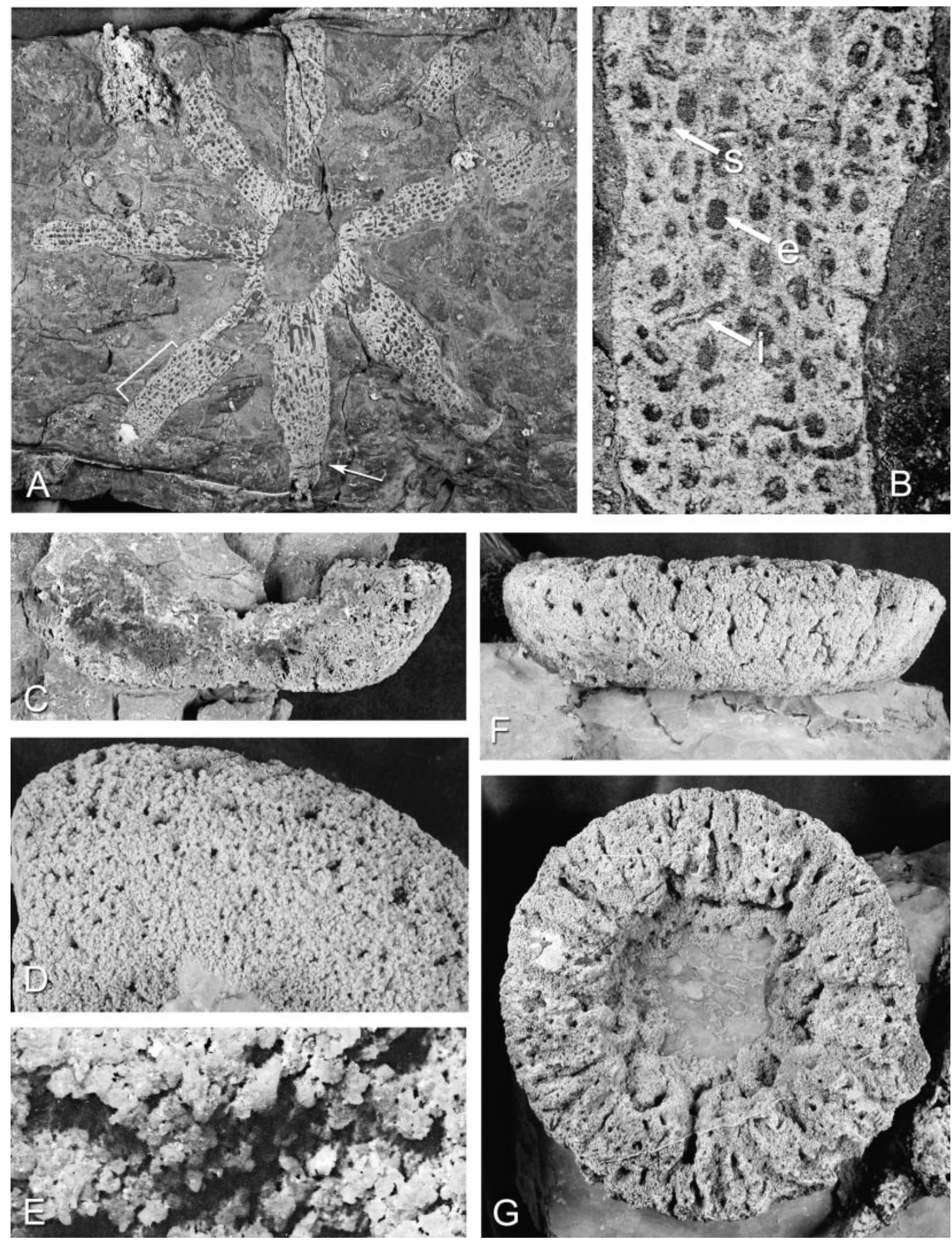
Fig. 3. Specimens of the demosponges Aulocopella winnipegensis Rauff 1895, and Hudsonospongia? sp., from the Richmondian Beaverfoot Formation, Top of the World Provincial Park, British Columbia. (A, B) Aulocopella winnipegensis Rauff 1895. (A) View of bedding plane showing a more or less horizontal section through the very large, radially digitate sponge, with canaled digitations spaced $\sim 30^{\circ}$ apart, of moderately uniform width, and attached to the thin wall of the circular central spongocoel; bracket on blade in lower left indicates area magnified in Fig. 3B, and arrow indicates radial oblique section through a blade, see text; TMP 93.113.1, locality L1213, $\times$ 0.32. (B) Detail of one of the arms showing large exhalant canals (e), subhorizontal inhalant canals (i), and steeply inclined inhalant canals (s), $\times$ 2.0. (C-G) Hudsonospongia? sp. (C) Vertical section through sponge showing generalized growth form of smaller representatives, with thick walls and flat-bottomed upper spongocoel, with moderately coarse inhalant canals in the silicified skeleton, TMP 89.30.2, talus at locality L1213, $\times 0.95$. (D) Partially exposed base and wall, with matrix wedge at lower center, showing relatively small, uniformly distributed, inhalant ostia in slightly enlarged silicified skeleton, TMP 89.30.2, talus at locality L1213, $\times 1.3$. (E) Photomicrograph showing microspheroidal siliceous replacement of skeleton TMP 93.113.12, from talus at locality L1213, $\times 18$. (F, G) TMP 92.95.6. (F) lateral view, $\times$ 0.58. (G) Vertical view down onto upper surface of sponge with thick walls around a shallow flat-bottomed spongocoel; coarse exhalant canals are prominent in the inner part of the sponge wall and finer, often intervening, inhalant canals show in the outer part of the wall, locality L1213, $\times 0.58$.

TYPE SPECIES: Hudsonospongia cyclostomata Raymond and Okulitch, 1940.

DIAGNOSIs: Broadly obconical to pyriform sponges with central spongocoel or cloacal depression of varying depth on upper surface; axial cluster of vertical exhalant canals common along with convergent radial inhalant and exhalant canals in upper part of sponge wall; less common, smaller, upward and outward divergent canals that parallel trabs of skeletal structure, in which I-shaped dendroclones are major elements.

Hudsonospongia? sp.

Figs. $3 \mathrm{C}-3 \mathrm{G}$

DESCRIPTION: Three silicified specimens occur in the collection. The larger of these, TMP 92.95.6, is a thick-walled, bowlshaped sponge (Figs. 3F, 3G) that is $15 \mathrm{~cm}$ in diameter and $\sim 4 \mathrm{~cm}$ tall. It has a shallow bowl-shaped spongocoel that is $7.5-8 \mathrm{~cm}$ in diameter and $\sim 1.5 \mathrm{~cm}$ deep, with a broad rounded base that is still partially matrix-filled. It is surrounded by thick walls that range $3.5-4.0 \mathrm{~cm}$ thick at the oscular margin. The base of the sponge is incompletely exposed and may be nearly flat to slightly uparched. The base of the sponge, beneath the spongocoel, is $\sim 1.5 \mathrm{~cm}$ thick, or perhaps slightly less if the dermal layer is uparched.

A coarse canal system that includes moderately large exhalant canals extends from a few $\mathrm{mm}$ inside the dermal layer to the spongocoel or gastral margin. The canals are roughly horizontal in the upper part of the wall but rise upward and inward from lower slopes of the sponge, and are essentially short vertical openings that empty into the central basal part of the spongocoel. They range from subcylindrical to distinctly flaring openings. They originate in the outer 1$2 \mathrm{~cm}$ part of the wall, where several finer inhalant canals merge to produce canals $3-5 \mathrm{~mm}$ in diameter. These canals generally expand inward to $7-8 \mathrm{~mm}$ in diameter near the gastral margin, but some flare to $10-12 \mathrm{~mm}$ in diameter at the spongocoel or exhalant surface and may have circular to ovoid or even irregular triangular cross-sections. The canals are separated by $8-15 \mathrm{~mm}$ of skeletal material that may be perforated by smaller subcylindrical exhalant canals, which may be only 3-5 $\mathrm{mm}$ in diameter, like the outer ends of the larger canals. The smaller canals are only separated by $2-$ $3 \mathrm{~mm}$ of skeletal material.

Inhalant ostia range $1-2 \mathrm{~mm}$ in diameter on the dermal surface, with most near $1 \mathrm{~mm}$ across, and they open into inhalant canals that are commonly $2 \mathrm{~mm}$ or slightly larger in diameter in outer parts of the wall. Most of the inhalant ostia are spaced $4-8 \mathrm{~mm}$ apart, although some may be spaced as much as 10-12 mm apart, particularly in the rounded lower part of the wall. They are fairly regularly spaced, although not aligned. In upper parts of the wall some of the canals have subvertical tangential surficial or dermal beginnings, but then slope downward and inward, initially, to become horizontal within $\sim 1 \mathrm{~cm}$ as they are traced inward to where they merge and produce the exhalant canals. A few scattered ostia also occur on the lower rounded basal part of the wall and become smaller and less common toward the base. There are still a few widely scattered ostia on the exposed nearly flat base of the sponge, where they are $<1 \mathrm{~mm}$ in diameter.

Subvertical canals occur between the inhalant-exhalant systems in the upper part of the wall. These vertical openings interconnect some radial series and pierce skeletal tracts between them. The canals are generally $\sim 0.5 \mathrm{~mm}$ in diameter, but appear somewhat irregular, perhaps because of the coarse spheroidal replacement and weathering of the surrounding skeleton.

Spicule structure of the sponge is not preserved in the coarse siliceous replacement, although locally an ill-defined upward and outward divergent structure is suggestive, but not definitive, of trabs of the streptosolenid or anthaspidellid structure.

The intermediate-sized sponge, TMP 93.113.12, is also a silicified, thick-walled, low bowl-shaped sponge. It is 9$10 \mathrm{~cm}$ in diameter and over $2.5 \mathrm{~cm}$ tall, but determination of total height is impossible for much of the base is still embedded in gray dolomite. The shallow, broad, spongocoel is $\sim 1 \mathrm{~cm}$ deep, with a gently sloping, perforate gastral surface, extending down from the nearly flat upper part of the surrounding wall. This results in an ill-defined osculum 4 $5 \mathrm{~cm}$ across. Upper walls are $2.5-3 \mathrm{~cm}$ thick and lower walls are only $\sim 1 \mathrm{~cm}$ thick. Thickness of the base cannot be determined, for the lower part of the spongocoel is also filled with gray matrix.

Walls are porous, with abundant inhalant and exhalant canals clearly evident. Coarse exhalant canals pierce much of the inner wall and are 3-5 $\mathrm{mm}$ in diameter, with most 3.5$4.0 \mathrm{~mm}$ across. They are more or less cylindrical, originate within a few millimetres of the dermal layer, and expand slightly to 5-6 $\mathrm{mm}$ across at the gastral surface. There they are irregularly 3-6 $\mathrm{mm}$ apart, where best preserved in the 
lower part of the exposed gastral surface, 1-2 $\mathrm{cm}$ below the oscular margin. Inhalant ostia are $1-1.5 \mathrm{~mm}$ in diameter on the dermal surface, where they are abundant and spaced $\sim 1.5 \mathrm{~mm}$ apart. Smaller skeletal pores, and perhaps ostia to smaller inhalant canals, occur in the skeletal spaces between the larger openings. These smaller pores are $\sim 0.4-0.5 \mathrm{~mm}$ in diameter, and the openings from them appear to merge in the outer part of the wall with inhalant canals from the larger ostia. These inhalant canals apparently form openings between the larger exhalant canals throughout the wall, for they both are evident on the upper surface of the wall.

Skeletal details, as in associated examples of the species, have been destroyed by microspheroidal silicification (Fig. 3E). These spherical elements are $0.2-0.5 \mathrm{~mm}$ in diameter and are composed of clusters on micronodules, $0.02-0.06 \mathrm{~mm}$ in diameter, that produce nodose surfaces over all elements of the coarsely silicified skeleton.

The smaller sponge, TMP 89.30.2, is also coarsely silicified and has weathered so that the flat to gently uparched base and upward curved dermal surface of the low wall are well exposed (Fig. 3C), but the upper part of the sponge and the spongocoel are largely buried in matrix. It is a low, broad, bowl-shaped sponge 7-9 $\mathrm{cm}$ in diameter and $20-25 \mathrm{~mm}$ tall. The relatively thick wall is $2 \mathrm{~cm}$ across at its flat summit, at the broad osculum, and the essentially flat base is $17-18 \mathrm{~mm}$ thick.

Ostia of three series of inhalant canals are evident in the heavily silicified dermal surface of the sponge. Coarse inhalant ostia and canals are $2.0-2.3 \mathrm{~mm}$ in diameter and are spaced irregularly 1.0-1.5 $\mathrm{mm}$ apart in the dermal layer of the steep upper part of the wall and on the outer rounded margin of the base. They appear to extend to about midwall, in the limited area where they can be seen, and are essentially horizontal in the upper wall but rise gently upward in the lower part of the wall and outer base. Ostia of intermediate-sized inhalant canals are more common and range $0.7-1.2 \mathrm{~mm}$ in diameter. They are irregularly spaced 1-2 $\mathrm{mm}$ apart in the dermal layer of both the wall and the base. They are the major openings in the base of the sponge (Fig. 3D). Abundant inhalant ostia of a third and finer series are $0.4-0.5 \mathrm{~mm}$ in diameter and only $0.5-1.0 \mathrm{~mm}$ apart in a regular, but not aligned nor patterned, distribution throughout the exposed exterior of the sponge.

Ostia of only three exhalant canals are partially exposed in the weathered gastral surface of the lower part of the shallow, still largely matrix-filled, spongocoel. They are 5-6 $\mathrm{mm}$ in diameter and 3-7 $\mathrm{mm}$ apart. Neither exhalant nor inhalant canals are evident in much of the massive dense silicified interior of the sponge exposed in cross-section on a vertical broken surface.

Skeletal structure is obscure in the small sponge for it has been heavily silicified and now appears largely microspheroidal where exposed and weathered, but dense and massive in the unweathered interior.

None of these sponges show any evidence of a holdfast or spicular tuft, with the bases being flat or slightly arched.

DISCUSSION: Certain identification to even family or genus level represented by these three impressive sponges is impossible because skeletal details have not been preserved.
However, they are all placed, with question, in Hudsonospongia based on their general growth form and canal patterns.

They are all within the normal size range for species of the genus, even though they are associated with the large specimen of Aulocopella winnipegensis.

MATERIAL: The larger specimen, TMP 92.95.6, was collected from a bedding plane in the Lower Beaverfoot Formation above Sparkle Lake, at locality L1213, and the sponge was in growth position, with the osculum opening upward. The other two specimens, TMP 89.30.2 and 93.113.12, were collected from talus at the same locality. Their original orientation with reference to bedding is uncertain in the relatively massive carbonate matrix.

\section{Genus Aulocopella Rauff, 1895}

TYPE SPECIES: Aulocopella winnipegensis Rauff, 1895.

DIAGNOSIs: Radially lobate to bladed sponge with deep obconical spongocoel; principal canals radially arched and generally subparallel to upper and outer surfaces, in stacked series in which exhalant ostia open into spongocoel; short inhalant canals smaller and converge through more dense dermal layer to meet larger exhalant openings; skeleton of dendroclones in rows perpendicular to outer surface and trabs and rows radiate from within basal part of sponge, beneath spongocoel; trabs diverge pinnately from vertical axes of blades or digitations.

DISCUSSION: Aulocopella was originally proposed as a subgenus of Aulocopium by Rauff (1895, p. 268), and he included the new species Aulocopium (Aulocopella) winnipegensis in the initial description. He also included Aulocopium (Aulocopella) cepa Roemer 1861 and listed it ahead of the new species. Bassler (1915, p. 96) recognized Aulocopella as a separate genus and listed Aulocopella winnipegensis as the type species, as did De Laubenfels (1955, p. E53). Rigby (1971, p. 44) suggested that because Roemer's species was treated first in Rauff's paper, it should probably be considered the type species. However, Roemer's species is not digitate and represents a growth form far from that of Aulocopella winnipegensis, and perhaps because of that reason, the Canadian species has been consistently cited as the type species of the genus by subsequent workers. We have followed that usage.

Aulocopella winnipegensis Rauff, 1895

Figs. 3A, 3B

Aulocopium (Aulocopella) winnipegensis Rauff, 1895, p. 269-271, pl. 24, figs. 4-6, text-fig. 124.

Aulacopella winnipegensis Whiteaves, 1897, p. 145-146, pl. 16, figs. 1-3, text-fig. 9; Bolton, 1960, p. 8.

Aulocopella winnipegenis Bassler 1915, p. 96; De Laubenfels, 1955, p. E53; Rigby, 1971, p. 44-49, pl. 4, figs. 1, 2, pl. 5, figs. 1, 2, 4, text-figs. 3, 4; Rigby and Leith, 1989, p. 550, figs. 2.3-2.6; Rigby and Johnson 2001, p. 71-73, figs. $2 a$, $2 b$.

DESCRIPTION: The large, essentially complete sponge, TMP 93.113.1, consists of a transverse section through the sponge (Fig. 3A), with a central, walled, circular spongocoel, from which radiate eight, more or less equally spaced, long, blade- 

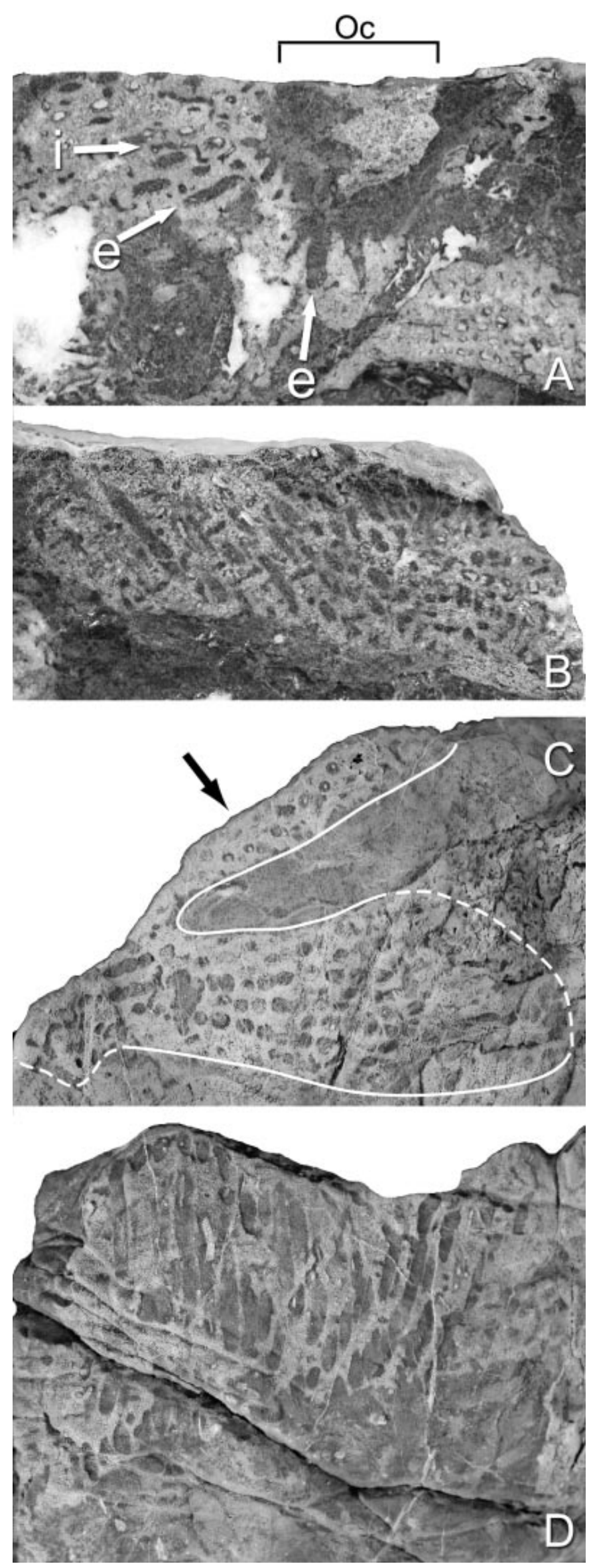

Fig. 4. Cross-sectional details in Aulocopella winnipegensis Rauff 1895, Beaverfoot Formation, locality L1213, Top of the World Provincial Park. All $\times$ 1. (A, B) TMP 93.113.1, sections exposed on vertical face of principal fracture across specimen (see Fig. 3A). (A) Vertical section through margin of matrix-filled spongocoel (Oc) showing radially arranged large exhalant canals (e) and subhorizontal inhalant canals (i) in the wall. (B) Vertical section through fin at 3:00 o'clock position in Fig. 3A, with common coarse exhalant canals and finer cross-connecting inhalant canals. (C, D) TMP 93.113.2, an incomplete specimen of the species with two partially preserved digitations. (C) Horizontal section through parts of two digitations with aligned ostia of exhalant canals, white line traces outline of fins; arrow indicates vertical face shown in Fig. 4D. (D) Large subbvertical canals in vertical section through fin.

like digitations. A major crack has split the specimen into two separate pieces (fitted together in Fig. 3A) and reveals an irregular vertical section through the central part of the sponge (Figs. 4A, 4B). As seen from above, the central spongocoel is ovoid and $4.3 \mathrm{~cm} \times 5.6 \mathrm{~cm}$ across, with a wall that ranges from 5 to $12 \mathrm{~mm}$ thick. The thinner measurement is probably through part of the lower wall, and the thicker one through an upper part, where proximal parts of the radial digitations have started to merge. An irregular vertical section along one side of the spongocoel (Fig. 4A) shows a matrix filling of at least $2 \mathrm{~cm}$, and suggests that it may be as deep as $4 \mathrm{~cm}$ in the central part of the obconical opening.

Eight radial bladelike digitations extend out from the spongocoel (Fig. 5) and are shown in nearly horizontal sections. They have expanded proximal ends where they merge with the spongocoel wall, but abruptly narrow distally and become more bladelike for most of their lengths. Most have rounded ends, but two show possible incipient bifurcation in the outer one or two centimetres of their sections. These digitations range from 13.0 to $15.2 \mathrm{~cm}$ long and up to $38 \mathrm{~mm}$ wide, with moderate variation. The apparently sloping radial section through one digitation, indicated by the arrow in Fig. 3A, is interpreted to show a narrow rounded base 10 $11 \mathrm{~mm}$ wide, in the outer part, but the blade broadens to maximum width of $35 \mathrm{~mm}$ at midheight and then narrows to 28-29 $\mathrm{mm}$ across at the rounded summit, based on distribution and sections of the curved, coarse, exhalant canals. Irregular vertical sections (Fig. 4B) suggest blades more than $35 \mathrm{~mm}$ tall, but it is uncertain how much of the upper blades had been removed by erosion before the sponge was collected. The maximum preserved diameter of the sponge is $33.3 \mathrm{~cm}$.

Three sets of canals are evident in sections. These include coarse tubular exhalant canals that are well shown in longitudinal sections in the proximal part of the lower digitation in Fig. 3A (arrow), and elsewhere in cross sections (e, Fig. 3B). Most of these canals are $2.0-2.5 \mathrm{~mm}$ in diameter, but range up to $3 \mathrm{~mm}$ in diameter. They are in radial rows in the digitations and spaced 2-3 per $\mathrm{cm}$, where they are subvertical and parallel in the lower parts of the digitations (Fig. 4D). They arch toward the spongocoel in upper parts of the digitations so that some sections of proximal parts of digitations show elongate, matrix-filled, canal segments where the canals have become nearly horizontal.

One set of inhalant canals (i, Fig. 3B) extends inward 
Fig. 5. Reconstructions in clay of Aulocopella winnipegensis and Hudsonospongia? sp. as unattached epifaunal reclining organisms. The large bladed Aulocopella winnipegensis is $33 \mathrm{~cm}$ in diameter, and the larger specimen of Hudsonospongia? sp. is $15 \mathrm{~cm}$ in diameter.

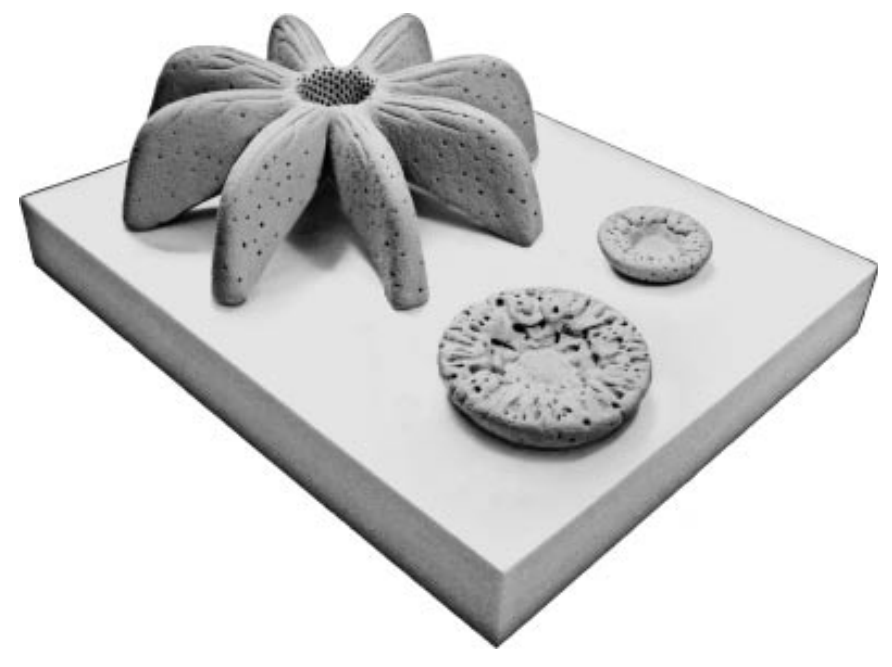

from dermal margins of the digitations and cross connect or empty into the exhalant openings, or occur between them in eroded sections. These inhalant canals range $1.0-1.4 \mathrm{~mm}$ in diameter, with most $\sim 1 \mathrm{~mm}$ across where most evident.

A third set of canals, which are also probably inhalant openings, are of the same general dimensions as the horizontal series but are more or less parallel to the coarse subvertical exhalant canals. These small canals (s, Fig. 3B) are scattered and appear as circular, matrix-filled openings in skeletal tracts between other canals in the available sections of the digitations.

Spicular structure of the skeleton was largely destroyed by the coarse crystalline dolomitization of the sponge, where crystals $0.05-0.20 \mathrm{~mm}$ across are now exposed. Locally, some variations in crystal textures suggest an aligned or parallel microstructure. That alignment appears to be parallel to former positions of skeletal trabs, like those described in other representatives of the genus and species, but there is no definitive structure in this fossil to show it has an anthaspidellid pattern.

The second fragment of the sponge includes parts of two radial fins (Fig. 4C) and has a vertical section through one of them, which shows the parallel, subvertical, coarse exhalant canals and an occasional transverse smaller inhalant canal, all filled with darker dolomitic matrix (Fig. 4D). The section suggests a fin $\sim 90 \mathrm{~mm}$ high.

DISCUSSION: This is by far the largest specimen of the gearshaped sponge discovered to date. It is unfortunate that its skeletal details have been obscured by coarse dolomitization. The holotype fragment (Rauff, 1895) has parts of five incomplete blades preserved, and is now only $\sim 11 \mathrm{~cm}$ across (Rauff 1895, p. 271; Rigby 1971, p. 46-49). If one extends the opposed blades to a possible maximum, this suggests a sponge $\sim 15 \mathrm{~cm}$ in diameter and $7 \mathrm{~cm}$ high. This contrasts with the Beaverfoot specimen, described here, which has a maximum preserved diameter of slightly over $33 \mathrm{~cm}$.

Other known specimens of the species are of more or less the same size as the holotype. For example, the other known specimen from Lake Winnipeg (Rigby and Leith 1989) is more nearly complete and is $\sim 9 \mathrm{~cm}$ across, as preserved, but if the eroded blades are restored, based on their taper, the sponge was probably only $12-13 \mathrm{~cm}$ in diameter and slightly smaller than the holotype. Similarly, the transported specimen of the species recovered in Montana (Rigby and Johnson 2001) is also slightly smaller, with a proposed restored diameter of $13-14 \mathrm{~cm}$.

MATERIAL: The large figured specimen, TMP 93.113.1, was collected by B. Campbell and P. Johnston from talus of the Beaverfoot Formation at TMP locality L1213, above Sparkle Lake, in Top of the World Provincial Park, in southeastern British Columbia in 1993. The smaller fragment of the species, TMP 93.113.2, was also collected in 1993 from talus at the same locality by Robert Campbell.

\section{Acknowledgments}

PAJ thanks B.S. Norford and R.C. Frey for helpful discussion in the field. R.C. Frey discovered the large Aulocopella specimen during joint field work with PAJ in 1993. D. Sloan (Royal Tyrrell Museum) sculpted the clay models shown in Fig. 4. We appreciate the constructive reviews of the paper by Brian Norford and an unnamed reviewer, as well as by the Associate Editor Jisuo Jin.

\section{References}

Bassler, R.S. 1915. Bibliographic index of American Ordovician and Silurian fossils. US. National Museum, Bulletin 92 (2 vols.).

Beresi, M.S., and J.K. Rigby, 1993. The Lower Ordovician sponges of San Juan, Argentina. Brigham Young University Geology Studies, Vol. 39, pp. 1-63, 8 text-figs., 13 pls.

De Laubenfels, M.W. 1955. Porifera. In Treatise on Invertebrate Paleontology. Part E, Archaeocyatha and Porifera. Edited by R.C. Moore. University of Kansas (Lawrence, Kansas) and Geological Society of America, pp. E21-E112, text-figs. 14-89.

Elias, R.J. 1991. Environmental cycles and bioevents in the Upper Ordovician Red River - Stony Mountain solitary rugose coral province of North America. In Advances in Ordovician geology. Edited by C.R. Barnes and S.C. Finney. Geological Survey of Canada, Paper 90-9, pp. 205-211.

Foerste, A.F. 1929. The cephalopods of the Red River Formation of southern Manitoba. Denison University Bulletin, Vol. 29, No. 7, pp. 129-235, 29 pls.

Frey, R.C., and Norford, B.S. 1995. Ordovician nautiloid cephalopod faunas from southeastern British Columbia: biostratigraphic and biogeographic significance. In Ordovician odyssey: short papers for the Seventh International Symposium on the Ordovician System. Edited by J.C. Cooper, M.L. Droser, and S.E. Finney. Society for Sedimentary Geology, Pacific Section, Book 77, pp. 85-88.

Johns, R.A. 1994. Ordovician lithistid sponges of the Great Basin. Nevada Bureau of Mines and Geology Open-file Report 1994-1, 160 p., 16 pls., 16 text-figs.

Lévi, C. 1953. Sur une nouvelle classification des Démosponges. Comptes Rendu hebdomodaires des Séances de l'Acadèmie Sciences, 236(8): 853-855.

Liu B., Rigby, J.K., and Zhu, Z. 2003. Middle Ordovician lithistid sponges from the northern margin of the Tarim Basin, China. Journal of Paleontology, 77(3): 430-441, 6 figs.

Norford, B.S. 1969. Ordovician and Silurian stratigraphy of the southern Rocky Mountains. Geological Survey of Canada, Bulletin 176. 
Norford, B.S., and Cecile, M.P. 1994. Ordovician emplacement of the Mt. Dingley Diatreme, Western Ranges of the Rocky Mountains, southeastern British Columbia. Canadian Journal of Earth Sciences, 31: 1491-1500.

Rauff, H. 1895. Palaeospongiologie, Zweiter Theil. Fortsetzung. Spongien des Silurs. Palaeontographica, 43: 223-271, figs. 76-124, pls. 20-26.

Raymond, P.B., and Okulitch, V.J. 1940. Some Chazyan sponges. Bulletin of the Museum of Comparative Zoology, Harvard College, 86(5): 197-214, 4 text-figs., 7 pls.

Rigby, J.K. 1971. Sponges of the Ordovician Cat Head Member, Lake Winnipeg, Manitoba, Part III, Fossils of the Ordovician Red River Formation (Cat Head Member), Manitoba. In Contributions to Canadian Paleontology. Geological Survey of Canada, Bulletin 202, pp. 35-79, 8 text-figs., 6 pls.

Rigby, J.K., and Desrochers, A. 1995. Lower and Middle Ordovician lithistid demosponges from the Mingan Islands, Gulf of St. Lawrence, Quebec, Canada. The Paleontological Society Memoir 41 (also Journal of Paleontology, 69(4, supplement)), 35 p., 14 figs.

Rigby, J.K., and Jamison, P. 1994. Lithistid sponges from the Late Ordovician Fish Haven Dolomite, Bear River Range, Cache County, Utah. Journal of Paleontology, 68(4): 722-726, 3 figs.
Rigby, J.K., and Johnson, E. 2001. New occurrence of Aulocopella winnipegensis Rauff, 1895, in western Montana. Brigham Young University, Geology Studies, 46: 71-73, text-figs. 1-3.

Rigby, J.K., and Leith, E.I. 1989. Tiddalickia manitobensis, a new dictyosponge, and an unusual specimen of the lithistid sponge, Aulocopella winnipegensis Rauff, from the Ordovician of Manitoba. Journal of Paleontology, 63: 550-553, figs. 1, 2.

Rigby, J.K., and Webby, B.D. 1988. Late Ordovician sponges from the Malongulli Formation of central New South Wales, Australia. Palaeontographica Americana, Vol. 56, 147 p., 24. text-figs., 44 pls.

Roemer, F. 1861. Die fossile Fauna der silurischen diluvial-Geschiebe von Sadewitz bei Oels in Nieder-Schlesien. Breslau, Poland, pp. i-xvi, 1-82, 6 pls.

Schmidt, O. 1870. Grundzüge einer Spongien-Fauna des Atlantischen Gebietes, Leipzig, Germany, pp. i-iv, 1-88, 6 pls.

Sollas, W.J. 1875. Sponges. In Encyclopaedia Brittanica, 9th ed., London, UK, pp. 427-446, 26 figs.

Whiteaves, J.F. 1897. The fossils of the Galena-Trenton and Black River Formations of Lake Winnipeg and its vicinity: Palaeozoic Fossils. Geological Survey of Canada, 3(3): 129-242, pls. 16-22. 
Copyright of Canadian Journal of Earth Sciences is the property of NRC Research Press and its content may not be copied or emailed to multiple sites or posted to a listserv without the copyright holder's express written permission. However, users may print, download, or email articles for individual use. 